християнська література для дітей та методична література для батьків і вчителів. Здійснюється заняття по листуванню з вихованцями дитячих будинків та інтернатів. За допомогою спортивних ігор дітям пояснюють християнські цінності. Проводяться дитячі денні табори 3 вивченням англійської мови. Створено кореспондентські курси і он лайн навчання. Налагоджена культурно-просвітницька діяльність, розвиваються духовні здібності у дітей. Викладається християнська етика в загальноосвітніх школах. Сиротам і дітям із бідних сімей, інвалідів надається гуманітарна допомога.

\title{
Література:
}

1. Гебелайн Ф. Образ истины Божией. Международная ассоциация христианских школ. - 1995. - С. 25.

2. Дениел Э., Уэйд Д. Основы христианского образования. Симферополь - 2005. - С. 140.

3. Мокієнко М.М. «Пізній протестантизм в Україні: інституційний та суспільно-політичний аспекти (1991-2004 р.p.). Дис. На здобуття наукового ступеня канд. істор. наук.- Запоріжжя.-2007 - с.73

4. Моррис Г. Христиаское образование для реального мира. - М., «Пртестант», - 1993. - С. 127.

5. Уилхойт Д., Райкен Л. Эффективное преподавание Библии. C. 73 .

6. Школа без стен - Коростень: МЧП «Триада С»-2016 - 123 с.

DOI https://doi.org/10.30525/978-9934-588-80-8-1.65

\section{ІСТОРІОГРАФІЯ ОСВІТИ УЧНІВ ПОЧАТКОВОЇ ШКОЛИ У ВЕЛИКІЙ БРИТАНІї В 50-ТІ РОКИ ХХ СТОЛІТТЯ}

\author{
Чевелюк М. В. \\ аспірант кафедри іноземної філологї̈ та перекладу \\ Відкритий міжнародний університет розвитку людини «Украӥна» \\ м. Київ, Україна
}

Освіта у Великій Британії зазнала величезних змін у післявоєнні часи. Усі три рівні освіти - початкова, середня та вища, зазнавали занепокоєння 3 приводу неадекватності та нерівності на кожному 3 трьох етапах навчання. Обурення набуло поширення серед батьків, вчителів та адміністраторів. Наприкінці одинадцяти років правління торі заклики до змін досягали апогею. 
Надто очевидним стала система відбору у початковій освіті. Вона мала шкідливий вплив на шкільну організацію та на навчальну програму. На той час ще існувала теорія вродженого інтелекту Берта, яка була дискредитована психологами. Соціологи попереджали, що це самореалізоване пророцтво, яке поділяє дітей по типам освіти на основі соціального класу їх батьків.

Початкові школи на той час були ще відносно новими. 31928 року вони стали офіційними. У 50 -ті роки майже половина старих загальноосвітніх шкіл була реорганізована в початкові. Реорганізація тривала довго, це був повільний процес. Початкова освіта тепер визначалася двома етапами - школярі від п'яти до семи років та від семи до одинадцяти, або в одній початковій школі учні від п’яти до одинадцяти років.

На початку 1950-х років було вже ясно, що тристороння система i пов'язаний $з$ нею режим тестування робить шкідливий вплив на початкові школи з точки зору їх навчальної програми.

Іспити «The 11 Plus exams» на основі яких присуджувались місця в гімназії, дуже обмежували програму початкової школи [1, с. 9]. Робота вчителя повинна була бути фіксованою та орієнтуватися на усіх учнів в цілому, але через посилену підготовку до іспитів переважна кількість учнів четвертих класів витрачало майже весь час на відпрацювання тестових робіт для покращення балів. Таким чином, більшість навчальних програм йшло на швидку та точну підготовку англійської мови, арифметики та логіки.

До цього часу школи і досі притримували системи потокового передавання, яку пропагував Берт у міжвоєнні роки. Тобто учнів поділяли на класи А, В та С (а іноді і більше) відповідно до їх розумових можливостей. Брайан Саймон стверджував, що це мало три негативні наслідки для дітей: по перше, це практично визначало їхне майбутнє у віці шести-семи років; по друге, це призвело до «механічної та спотвореної форми навчання»; і по трете, це ізолювало дітей одне від одного, і так порушувало єдність школи [2, с. 18].

Опитування Брайана Джексона в 1962-19633 роках показало, що 96 відсотків шкіл, що поділяли дітей за такою схемою, передавали своїх учнів на наступний етап, не поділяючи їх знову; лише 4 відсотки цього не робили. Три чверті дітей до семи років були в навчальних класах, де відбувався поділ.

Групування всіх «просунутих» дітей в один клас, а «відсталих» - в інший також створювало умови, за допомогою яких відмінності між обома групами неминуче посилювались у процесі навчання. Отже, надалі поділ цих потоків був рідкісним [3, с. 152]. 
Всім було відомо, що дітей із сімей середнього класу, як правило, розподіляють до потоків А; дітей робочого класу до потоків С або Д. Що стосується вчителів, 85 відсотків тих, хто відповів, висловились за подальше потокове передавання класів для всіх типів вчителів та шкіл. Дітей, що навчалися у А-класах посилено тренували для складання тестів у середню школу. Це сприяло обмеженню і вузькості навчальної програми початкової школи, яка якісно готувала школярів лише за трьома предметами - англійська мова, арифметика та логіка, в результаті, була широко розкритикована.

31950 років деякі школи почали експериментувати 3 непрофільними класами. Джордж Фріленд, керівник однієї 3 трьох початкових шкіл Лестера, стверджував, що стандарти були підвищені, i школа функціонувала ефективніше як соціальна одиниця. Він вважав, що лише у випадку, де діти поділені згідно з розумовими особливостями, можна пропонувати дітям найбільші можливості. Також потрібно вдосконалити методи викладання, модифікувати навчальну програму 3 урахуванням власного досвіду та досвіду інших шкіл, що мають таку ж систему поділу, та продовжувати замінювати систему індивідуального змагання колективними зусиллями. Метою має бути формування позитивного освітнього та соціального духу в єдиній школі.

Інший керівник - Е. Харві, 3 початкової школи Weston Lane в Йоркширі, писав: «Після чотирьох років практики без потокової системи у мене сформувався щасливий та захоплений персонал, який віддає перевагу нинішній організації, рівень роботи покращився, а стосунки з батьками є прекрасними» [4, с. 47-49]. Він прийшов до висновку, що система, яка не розділяє учнів, дуже допомагає, коли нові ідеї перевіряються на практиці.

Справа проти поділу на класи «полягала головним чином у зростанні усвідомлення того, що звичайне формування дітей по класам на будь-якому рівні визначало життєві шанси дітей - часто з семи років або навіть раніше» [3, с. 347].

Дослідження показали, що надалі поділ між потоками був мінімальний (близько 2 відсотків), так що переважна більшість дітей залишалася у своєму початковому потоці протягом усього шкільного життя.

Дітей, які потрапляють у низький потік, відповідно до їхнього рівня здібностей, навчали повільнішими темпами; тоді як сильніші потоки, часто за участю кращих вчителів, заохочуються рухатися швидше [5, с. 43].

Після завершення початкової школи школярів знов поділяли, але вже на два, рідше на три, класи. 
На кінець 1950 років було створено дискусії та конференцій 3 приводу методів навчання та навчальних програм, для поліпшення навчального процесу.

\title{
Література:
}

1. Ріглі Т. Політика навчальної програми в школах. Політичний документ Лондон: Центр трудових та соціальних досліджень. Лондон, 2014.

2. Саймон Б. Тестування інтелекту та всеосяжна школа: Лоуренс та Вішар. Лондон, 1953 рік.

3. Саймон Б. Освіта і соціальний порядок 1940-1990: Лоуренс i Вішарт. Лондон, 1991. С. 152.

4. Харві Е. Розподіл молодшої школи: Форум 2 (2) Весна. Лондон, 1960.

5. Вернон П.Е. Відбір середньої школи. Дослідження Британського психологічного товариства: Methuen \& Co Ltd. Лондон, 1957.

DOI https://doi.org/10.30525/978-9934-588-80-8-1.66

\section{BLENDED LEARNING IN THE MODERN EDUCATIONAL PROCESS TRAINING OF MEDICAL PROFESSIONALS}

\author{
Shaposhnikova V. M. \\ Candidate of Medical Sciences, Head of the Department of professional \\ medical and pharmaceutical disciplines, Cherkassy Medical Academy \\ Cherepanova M. O. \\ Head of the Department of humanities and historical disciplines \\ Cherkassy Medical Academy \\ Kravchenko O. P. \\ Candidate of Pedagogical Sciences, a teacher of the department \\ of humanities, Cherkassy Medical Academy \\ Cherkassy, Ukraine
}

The purpose of the article. The purpose of the article is to reveal the topic of blended learning and the experience of using this innovative technology at the Cherkassy Medical Academy, as well as to demonstrate a number of advantages and disadvantages of blended learning.

Theoretical basics and research methods. Blended learning is one of the modern educational technologies, which is based on the concept of 248 